\title{
Nutrient cycling by Antarctic marine microbial plankton
}

\author{
Julian Priddle ${ }^{1}$, Ray Leakey ${ }^{1}$, Carolyn Symon ${ }^{1, *}$, Mick Whitehouse ${ }^{1}$, Dave Robins ${ }^{2}$, \\ Geof Cripps ${ }^{1}$, Eugene Murphy ${ }^{1}$, Nick Owens ${ }^{2, * *}$
}

${ }^{1}$ British Antarctic Survey, NERC, High Cross, Madingley Road, Cambridge CB3 0ET, United Kingdom
${ }^{2}$ Plymouth Marine Laboratory, NERC, Prospect Place, The Hoe, Plymouth PL1 3DH, United Kingdom

\begin{abstract}
Three sites along a shelf to deep-sea transect near the island of South Georgia $\left(55^{\circ} \mathrm{S}\right)$ were sampled in the latter part of the austral summer for water column structure, inorganic nutrients, particulate material and microplankton. Median concentrations at the 3 sites were 17 to $24 \mathrm{mmol} \mathrm{m}^{-3}$ nitrate and approximately $1.6 \mathrm{mmol} \mathrm{m} \mathrm{m}^{-3}$ phosphate, whilst silicate concentrations remained at $11 \mathrm{mmol} \mathrm{m}^{-3}$ nearshore but were reduced to approximately $1 \mathrm{mmol} \mathrm{m}^{-3}$ offshore. Microplankton community composition appeared to be characteristic of post-bloom conditions. Heterotrophs, including large protists, dominated microbial biomass at the offshore site. Pigment characterisation was consistent with the domination of the microplankton by diatoms at all sites. Changes in the carbon and nitrogen content of particulate material down the water column were consistent with significant remineralisation of nitrogen in the mixed layer, with molar C:N ratios of 6.5 to 7.7 in surface waters and up to 11.9 immediately below the mixed layer. In most cases, peak concentrations of ammonium were found to be associated with the pycnocline, suggesting that remineralisation of nitrogen was occurring here. However, no component of the microbial community could be associated with this region of ammonium production. Carbon fixation over the growing season predicted from published instantaneous nitrogen uptake rates, from biological nitrate deficit in the mixed layer and from the corresponding silicate deficit suggested that at least $25 \mathrm{~g} \mathrm{C} \mathrm{m}^{-2}$ was produced by phytoplankton during the growth season. However, there is strong evidence that this is a serious underestimate. Even whilst nitrate concentrations remained high, ammonium and possibly other 'recycled nitrogen' appeared to be key inorganic nutrients. Particulate carbon and silicon appeared to be removed from the mixed layer whilst nitrogen was regenerated in situ. In such systems, nitrate removal does not indicate carbon export, and nitrogen recycling may be a crucial factor in determining productivity throughout the growing season.
\end{abstract}

KEY WORDS: Nutrient cycling · Antarctica - Carbon export - Marine microplankton - Nitrogen · Silicon · Particulate material $\cdot$ Community composition

\section{INTRODUCTION}

The dominating perception of the seasonal dynamics of oceanic microplankton derives from regions where a spring bloom is initiated by both increasing insolation and a decreased depth of mixing, but then declines

\section{Present addresses:}

- Oslo and Paris Commissions, New Court, 48 Carey Street, London WC2A 2JE, United Kingdom

- Department of Marine Science and Coastal Management, The Ridley Building, The University of Newcastle upon Tyne, Newcastle upon Tyne NE1 7RU, United Kingdom after the major source of nitrogen - nitrate injected into the mixed layer from below in winter - is utilized. The paradigm of new and regenerated production (Dugdale \& Goering 1967) is predicated on the ability to identify that part of the nutrient pool which is replaced annually, thereby defining the upper limits to community carbon uptake and export. Features of the microbial community follow this annual cycle (Cullen 1991) - diatoms dominate the spring bloom and are consumed by large herbivores, whilst the regenerative phase of the community comprises smaller primary producers grazed by microheterotrophs in the microbial loop. However, the use of the nitrate amount in the 
mixed layer to define the total annual new production has been challenged on various grounds. First, the nitrate pool may not be closed, either on local scales (e.g. Sambrotto \& Langdon 1994) or on large scales (e.g. Jacques 1991, Jacques \& Fukuchi 1994). Alternatively, the utilisation of inorganic carbon and nitrogen may be decoupled (Banse 1994), or differences in export fluxes from the euphotic zone may mean that recycled nitrogen may fuel carbon export (Sambrotto et al. 1993).

Parts of the oceans, sometimes characterised as 'high nutrient, low chlorophyll' (HNLC; see Chisholm \& Morel 1991), do not conform to this stereotype introduced by Dugdale \& Goering (1967). In these regions, nutrient concentrations are not reduced to limiting levels by the spring bloom. New and recycled production are not separated temporally, at least not in the ordered sense apparent from the classical picture. The reasons why nutrients remain underutilized remain the subject of debate, and have received renewed attention because HNLC areas might be regions where carbon dioxide drawdown to the oceans may be enhanced (Priddle et al. 1992). The largest of such regions is the Southern Ocean, where summer nitrate concentrations are commonly of the order of 10 to $30 \mathrm{mmol} \mathrm{m}^{-3}$ in surface waters. These values are comparable to, or higher than, winter surface nitrate concentrations in the North Atlantic (Garside \& Garside 1993). Primary production in the Southern Ocean is low, approximately $1.2 \mathrm{Gt} \mathrm{C} \mathrm{yr}^{-1}$ for approximately $10 \%$ of the world's ocean surface, whereas the global total is estimated to be 27 Gt (Smith 1991).
An improved understanding of the microbial dynamics within HNLC areas is needed both to test the different hypotheses for mechanisms controlling primary production and also to examine critically the application of concepts of nutrient-based definitions of export production where a single annual pulse of new productivity cannot be delineated. This study describes an investigation of the dynamics of the microbial community in the vicinity of a Subantarctic island, at a time when phytoplankton growth had already proceeded for 2 mo or more, and where a well-developed heterotrophic microbial community existed alongside large diatoms and crustacean grazers.

\section{METHODS}

Study site and transect. The study was carried out during the austral summer on a shelf to deep-sea transect to the northwest of South Georgia, a relatively large Subantarctic island in the northern Scotia Sea (Fig. 1). South Georgia is surrounded by an extensive and deep continental shelf and is an important focus for primary and secondary production within the Scotia Sea. The oceanographic conditions around the island are highly variable. In terms of the large-scale oceanography, Antarctic Surface Water (ASW) is generally located to the north and west of South Georgia and Weddell Sea Water to the south and east.

Samples were obtained at 3 stations along a $110 \mathrm{~km}$ southeast-northwest transect - Stn 2 occurred on the shelf and had a maximum water depth of $230 \mathrm{~m}$,

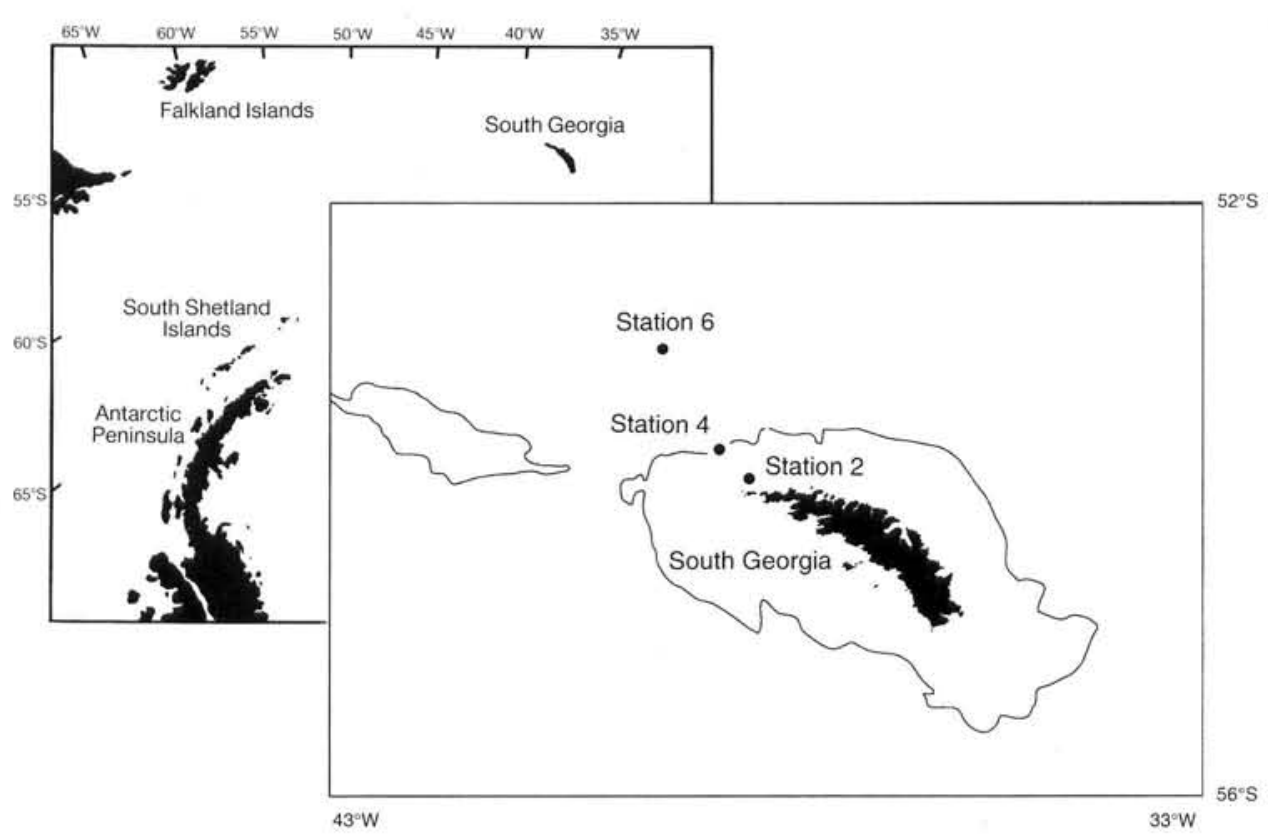

Fig. 1. Study site, indicating the 3 stations discussed in the text. Inset shows the location of South Georgia (isobath is $500 \mathrm{~m}$ ) 
Stn 4 was on the slo, : and had a water depth of $500 \mathrm{~m}$, whilst Stn 6 was fully oceanic with a water depth of almost $4000 \mathrm{~m}$. Sampling occurred during January 1990 and each station was occupied for approximately $3.5 \mathrm{~d}$, during which time a range of physical, chemical and biological measurements were made. Data from some of these investigations have already been published (Owens et al. 1991, Atkinson et al. $1992 a, b)$.

Sampling and physical and chemical analyses. Several samples were taken at each station, and used for a wide range of analyses and experiments. In many cases in this paper, data from profiles are combined, or derived from a unique profile at that station. Where individual samples from defined stations are referred to, they are identified by a 'sampling event number' (e.g. see Fig. 2 and Table 7).

Water samples were collected using a General Oceanics water bottle rosette system mounted on a Neil Brown Mark 3 CTD. The CTD was tank-calibrated for temperature and pressure (depth) before and after the cruise. Water samples for salinity calibration were taken during the course of the project, and their conductivity measured using a Guildline Autosal.

Filtered water samples (Whatman GF/C: nominal particle retention $1.2 \mu \mathrm{m}$ ) were analyzed for dissolved nitrate + nitrite $\left(\mathrm{NO}_{3}-\mathrm{N}+\mathrm{NO}_{2}-\mathrm{N}\right)$, ammonium $\left(\mathrm{NH}_{4}\right.$ $\mathrm{N})$, phosphate $\left(\mathrm{PO}_{4}-\mathrm{P}\right)$ and silicate $\left[\mathrm{Si}(\mathrm{OH})_{4}-\mathrm{Si}\right]$. Nitrite concentration was not subtracted from the nitrate value, but the former is typically only about $1 \%$ of the combined amount around South Georgia (Whitehouse et al. 1993). Details of methods are provided by Whitehouse \& Woodley (1987), who indicate that precision was better than $\pm 1 \%$ for all analyses. Minimum levels of detection provided by Whitehouse \& Woodley (1987, their Table 5) were all significantly lower than the concentrations encountered during the present study, except for a few silicate and ammonium analyses. Nutrient chemical data were also obtained from the British Antarctic Survey (BAS) Marine Life Sciences database and from data held at the British Oceanographic Data Centre.

Concentration of chlorophyll a ( $\mathrm{chl}$ a) was determined for particulate material retained by glass fibre filters (Whatman GF/F: nominal retention $0.7 \mu \mathrm{m}$ ) after pre-screening through a $200 \mu \mathrm{m}$ mesh. Replicate filters from known volumes of seawater were frozen at $-25^{\circ} \mathrm{C}$ until analysis in the UK. Filters were extracted in $90 \%$ $\mathrm{v}: \mathrm{v}$ acetone:water, and chl a concentration in the extract measured spectrophotometrically (Pye-Unicam SP8-100) using the equations of Strickland \& Parsons (1972, p. 193). A second pair of replicate filters (precombusted GF/F) were frozen at $-25^{\circ} \mathrm{C}$ for analysis of total- and organic-particulate carbon and nitrogen. Prior to analysis, the filters were dried at $55^{\circ} \mathrm{C}$ and stored in a desiccator. Subsamples from each filter were then taken using a punch of known area - at least 3 subsamples were used for each $\mathrm{C}-\mathrm{N}$ analysis. More than 1 set of subsamples was analyzed for each filter pad. Analysis for particulate $\mathrm{C}$ and $\mathrm{N}$ was then undertaken on an elemental analyzer (Carlo Erba model 1106). The filter pad remaining after subsampling was then ashed in a low-temperature plasma asher to drive off the organic fraction. Subsequent elemental analysis provided the concentrations of the remaining inorganic $\mathrm{C}$ and $\mathrm{N}$, which were subtracted from total values to give the concentrations of organic material used here. Particulate biogenic silica in material retained by a $2 \mu \mathrm{m}$ pore size polycarbonate membrane filter was analyzed for the offshore site approximately $1 \mathrm{mo}$ later than the other samples were obtained, using the method of Paasche (1980). Separate samples of particulate material were obtained for detailed pigment analysis by filtering 301 of seawater through large glass fibre filter pads (Whatman GF/F), from sediment traps (approximately $50 \mathrm{~m}$ depth) and from vertical net hauls (mesh size $20 \mu \mathrm{m}, 50 \mathrm{~m}$ depth to surface). Sampling was undertaken around midday, and all samples were extracted and analyzed using high-performance liquid chromatography (HPLC) following Mantoura \& Llewellyn (1983).

Microbial analyses. The abundance and biomass of bacteria and nanoflagellates were determined from filtered samples analyzed by epifluorescence microscopy (Hobbie et al. 1977, Porter \& Feig 1980). Three replicate $10 \mathrm{ml}$ samples were preserved in $2.5 \%$ final concentration glutaraldehyde, stained with $5 \mathrm{\mu g} \mathrm{ml}^{-1}$ final concentration DAPI, concentrated onto $0.2 \mu \mathrm{m}$ pore size Nuclepore polycarbonate filters, and examined at $\times 1250$ magnification under UV illumination. To determine bacterial abundance and carbon biomass, bacterial cells were enumerated from 25 fields of view from each filter. Bacteria were identified by their blue fluorescence and grouped into 3 size categories: 0.5-1.0 $\mu \mathrm{m}$ diameter cocci, $0.5-1.0 \mu \mathrm{m}$ long rods and $1.0-1.5 \mu \mathrm{m}$ long rods. Mean population abundance and biovolume were then calculated using cell volume estimates, and carbon biomass was calculated using a

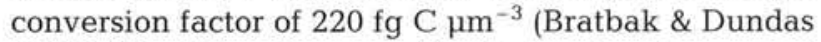
1984). To determine nanoflagellate abundance and biomass, cells were enumerated from 50 fields of view from each filter. Flagellate cells were identified by their blue fluorescence and classified into distinct taxa according to size and shape. The cell volume of each taxon was then calculated by equating the shape of each cell to a standard geometric figure, and mean population abundance and biovolume calculated. Carbon biomass was then calculated from population biovolume using the conversion factors of Eppley et al. (1970). 
The abundance and biomass of diatoms, dinoflagellates and ciliates were determined from settled samples analyzed by inverted microscopy following the methodology of Utermöhl (1958). Three replicate $50 \mathrm{ml}$ samples were preserved in $1 \%$ final concentration acid Lugol's, concentrated by settling for $48 \mathrm{~h}$, and examined at $\times 400$ magnification. To determine abundance and biomass, cells were enumerated from either the whole or a representative proportion of the settling chamber. Mean population abundance and biovolume, and diatom and dinoflagellate carbon biomass, were then calculated from cell volume as for nanoflagellates. To determine ciliate carbon biomass, population biovolumes were converted to carbon mass using a factor

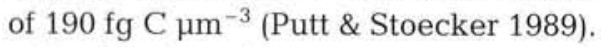

Statistical analyses were undertaken using the SAS and Minitab packages (SAS 1985, Ryan et al. 1988). Principal Components Analysis (PCA) was used to reduce the large microplankton species composition data sets. As these data were derived from several different counting procedures, biomass was re-scaled to be a proportion of the total biomass for the appropriate counting method, in order to standardise the expression of abundance for the different microplankton groups. This method avoided any inconsistencies arising from the different counting techniques, and enabled more scarce groups, such as protists, to be better represented in the ordination.

\section{RESULTS}

\section{Water column structure}

Water column structure was similar at the 3 sites and typical of conditions to the south of the Polar Front. This region, the Antarctic Zone, is typified by a layer of relatively cool, fresh ASW (approximately $200 \mathrm{~m}$ thick) overlying a thicker layer of warmer, saltier and nutrient-rich Circumpolar Deep Water (CDW). As all the biological and chemical samples were obtained from the upper layer this description focuses on ASW only.

During the austral summer ASW has a seasonal mixed layer of approximately $50 \mathrm{~m}$ at the surface. This less-dense surface layer results mainly from ice melt (and surface runoff near land) and is underlain by a strong seasonal halocline. Surface temperatures also show a strong seasonal signal, with mixed layer temperatures increasing during the summer, generating a thermocline of several degrees relative to the underlying 'winter water' (a remnant of the fully mixed ASW of the previous winter). Since there is a strong permanent thermocline between ASW (i.e. the base of the temperature minimum during summer) and the underlying CDW, seasonal heating at the ASW surface results in a
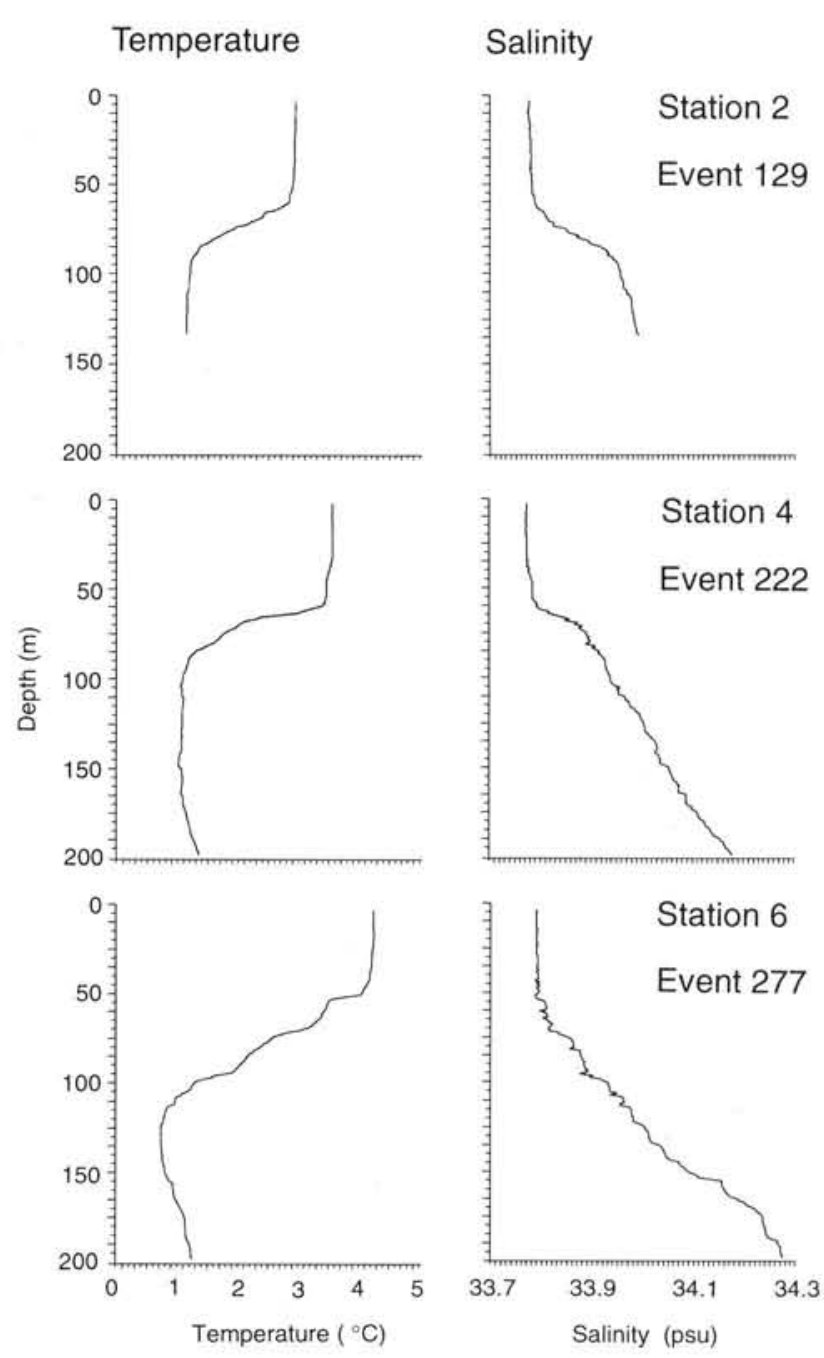

Fig. 2. Temperature and salinity profiles for the 3 stations near South Georgia

characteristic temperature inversion in the ASW during summer.

Fig. 2 shows typical temperature and salinity profiles for the 3 sites and Table 1 describes the major features of the surface mixed layers. Average mixed layer depths ranged from 50 to $60 \mathrm{~m}$ but individual profiles varied from 45 to $70 \mathrm{~m}$ according to changes in wind

Table 1. Average mixed layer properties for 3 stations near South Georgia. Mixed layer defined by an increase in the density gradient of $\geq 0.007 \mathrm{~kg} \mathrm{~m}^{-3}$

\begin{tabular}{|lccc|}
\hline Property & Stn 2 & Stn 4 & Stn 6 \\
\hline Depth (m) (range) & $60(55-68)$ & $57(48-65)$ & $50(46-58)$ \\
Temperature $\left({ }^{\circ} \mathrm{C}\right)$ & 2.9 & 3.5 & 4.3 \\
Salinity (psu) & 33.777 & 33.774 & 33.797 \\
\hline
\end{tabular}


stress. There was occasional, short-lived stratification closer to the surface during particularly calm weather. The salinity of the mixed layers varied - it was higher and less variable at Stn 6 than at Stns 2 and 4. Surface runoff, principally glacial meltwater, was likely to have been the major factor responsible for this difference between the onshore and offshore sites.

\section{Vertical and horizontal distribution of inorganic nutrients}

Nitrate, silicate and phosphate profiles were similar at all 3 stations, with a relatively homogeneous distribution over the mixed layer and a progressive increase in concentration with depth below this level (Fig. 3). This distribution is consistent with the resupply of nutrients to the ASW from the underlying CDW. Nitrate and phosphate concentrations in the mixed layer differed little between stations (Table 2) while silicate showed a pronounced gradient from onshore to

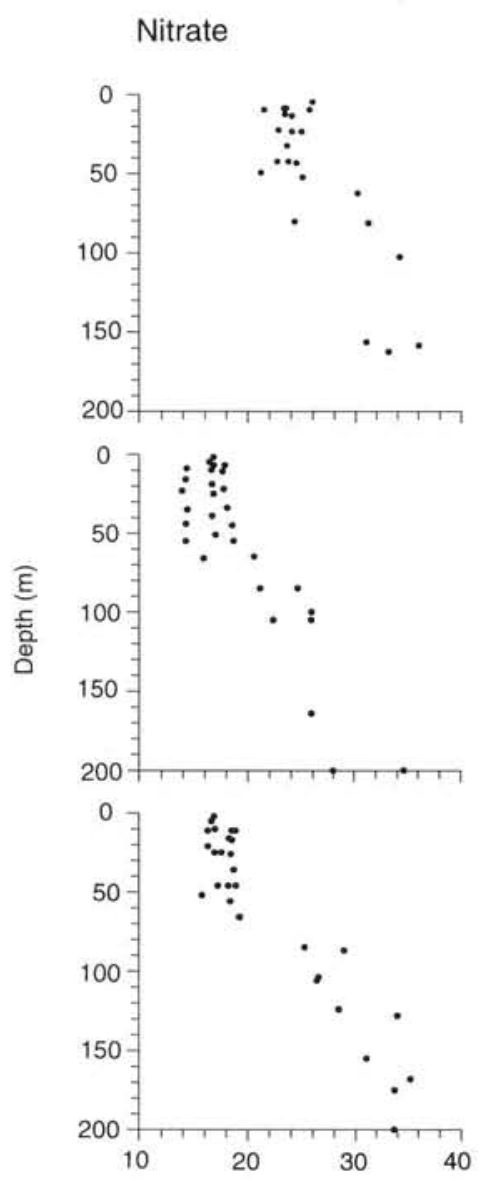

offshore. These silicate concentrations were very much lower than summer levels reported previously for South Georgia (Whitehouse et al. 1993). Although mixed layer silicate levels were lowest for Stn 6, below the mixed layer concentrations were similar at all 3 sites (Fig. 3, Table 2).

Nitrate, phosphate and silicate concentrations are considerably higher in the surface waters during winter, when the surface stratification has broken down and the ASW is fully mixed (Whitehouse et al. 1993). Table 2 summarises the data available from the BAS archives and compares these with the T-min nutrient levels from the present study. As the T-min layer represents the remnant of the winter mixed layer it is to be expected that these values will correspond well.

Ammonium profiles were very different from those of the other nutrients (Fig. 3). Concentrations ranged from undetectable to $1.6 \mathrm{mmol} \mathrm{m}^{-3}$. At Stns 2 and 4 , the peak in ammonium concentration appeared to be associated with the pycnocline, while profiles obtained at $\operatorname{Stn} 6$ were more variable.

\section{Ammonium \\ Silicate}
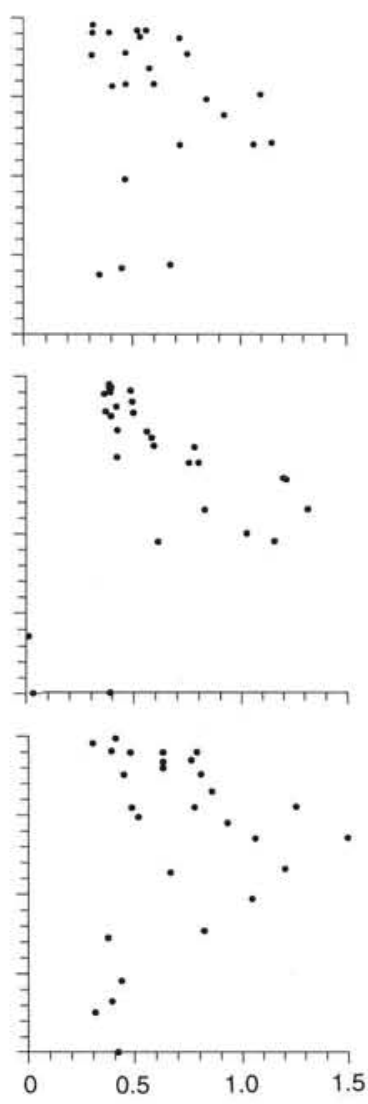
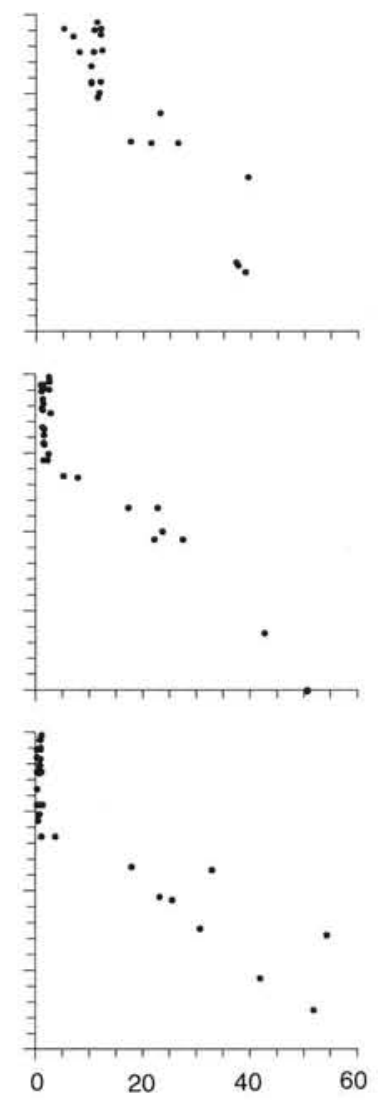

Phosphate
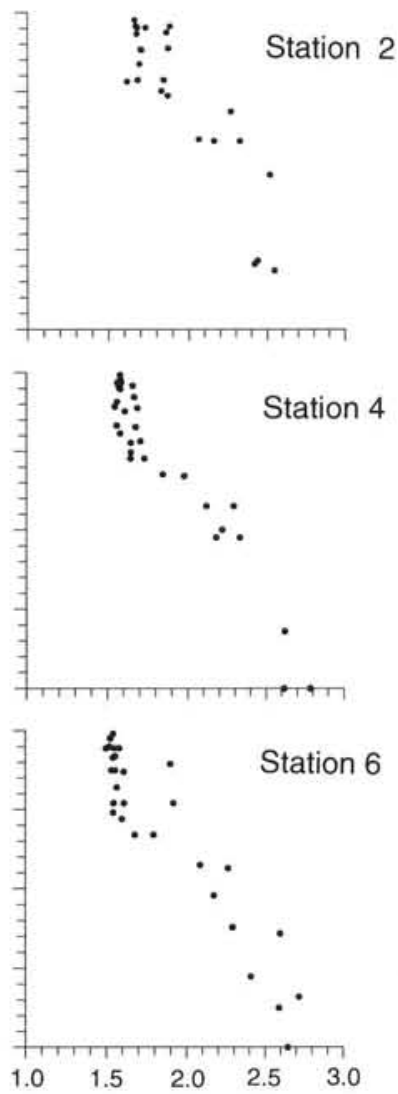

Nutrient concentration $\left(\mathrm{mmol} \mathrm{m}^{-3}\right)$

Fig. 3. Vertical profiles of nitrate, ammonium, silicate and phosphate concentrations for the 3 stations. Each scatter plot includes data from several profiles. Average mixed layer depths are given in Table 1 


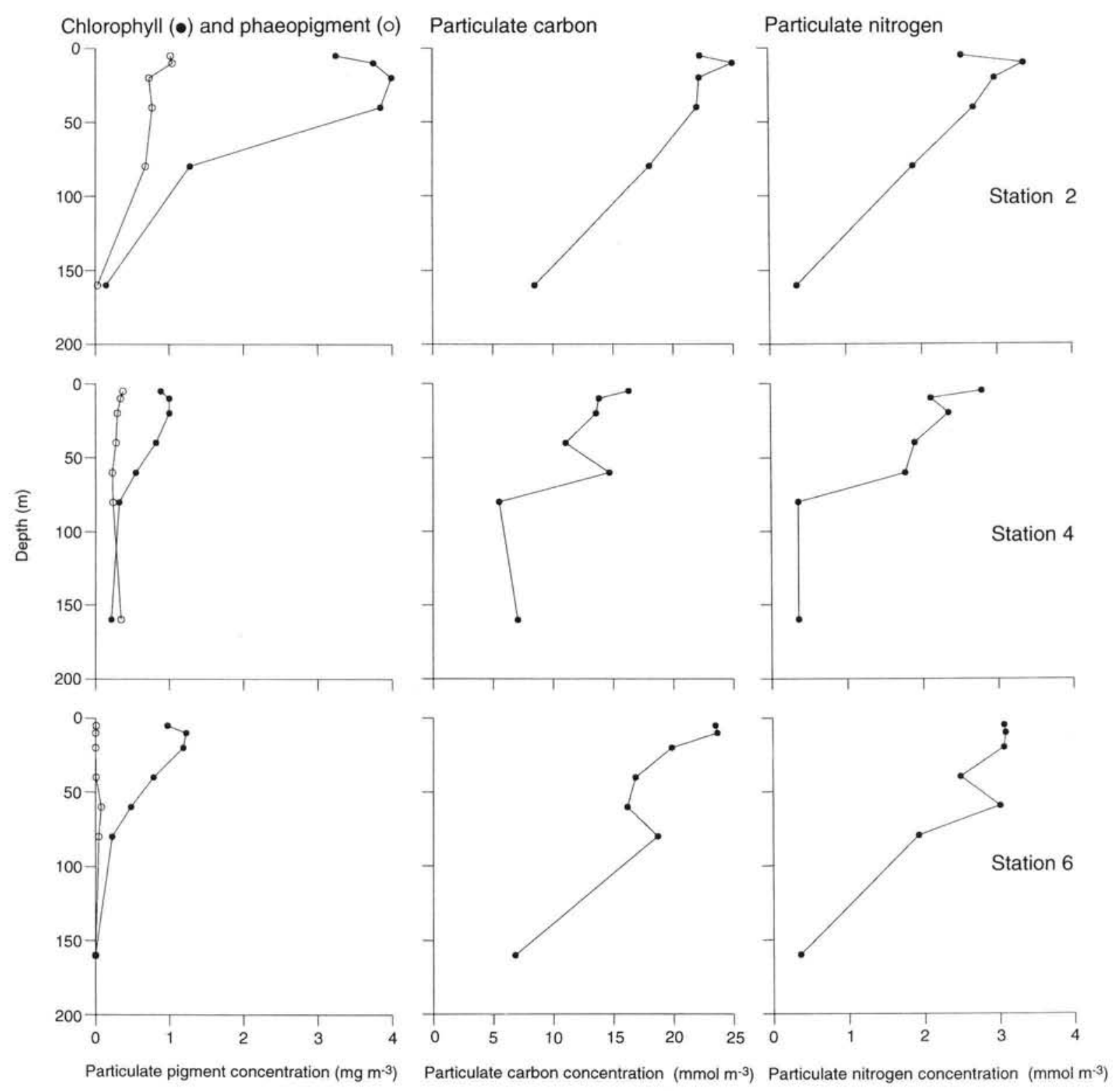

Fig. 4. Vertical profiles of chlorophyll $a$, and particulate organic carbon and nitrogen for the 3 stations. Data are derived from single profiles at each site (see Table 3)

water column at Stns 2 and 4 (70 to $90 \%$ of biomass), but accounted for less than half of the microbial biomass at Stn 6. At all 3 stations, the proportion of heterotrophic biomass increased with depth (Fig. 5, Table 4). Only very approximate estimates of total microbial biomass are possible for the upper water column. Integrations over the mixed layer suggest values of 4.5, 2.25 and $3.5 \mathrm{~g} \mathrm{C} \mathrm{m}^{-2}$ for Stns 2, 4 and 6 respectively, with corresponding proportions of autotrophic biomass being $0.66,0.66$ and 0.43 .

Microplankton $(\geq 20 \mu \mathrm{m})$, mostly diatoms, dominated the autotrophic microbiota in all samples (Table 4). No autotrophic picoplankton $(\leq 2 \mu \mathrm{m})$ were seen, although several nanoplankters $(2-20 \mu \mathrm{m})$ were encountered. The non-diatom phytoplankton also included Phaeocystis, autotrophic dinoflagellates, cryptomonads and a range of indeterminate taxa, predominately small phytoflagellates.

The heterotrophic microbes were equally diverse, but with 2 clear biomass groups. Microplankton again dominated the biomass in many samples, but bacteria (picoplankton) accounted for 25 to $50 \%$ biomass in shallow water and up to $90 \%$ of the biomass in the deepest samples (Fig. 5, Table 5). Differences between 


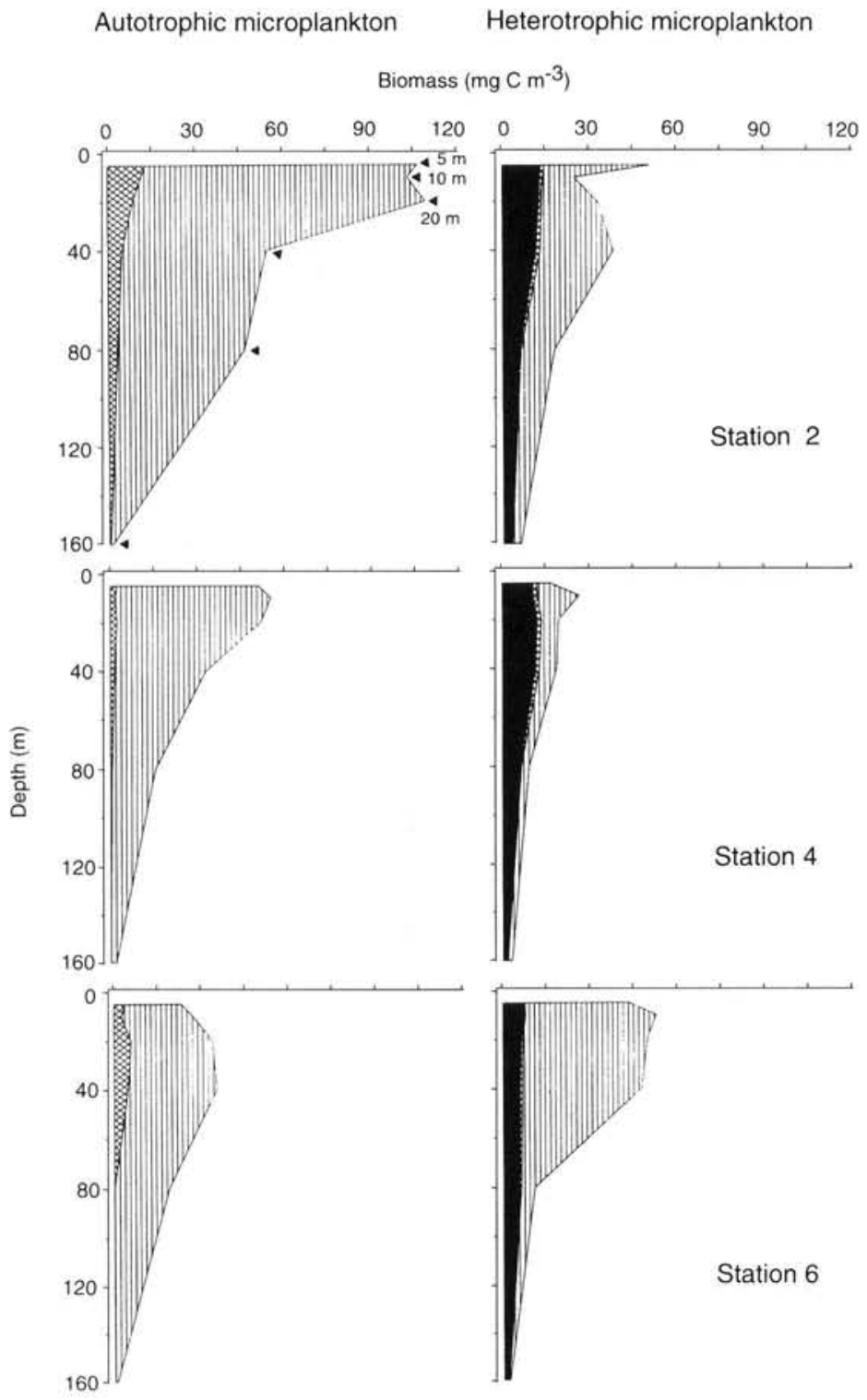

Fig. 5. Vertical profiles of the photoautotrophic and heterotrophic microbial biomass for the 3 stations. Biomass is classified by size: $0.2-2 \mu \mathrm{m}$ (black, heterotrophs only), 2-20 $\mu \mathrm{m}$ (cross hatching) and $\geq 20 \mu \mathrm{m}$ (vertical hatching). Data derive from single profiles (see also Tables 4 \& 5), and the sample depths used are indicated on the first panel

stations were evident in their heterotrophic microplankton populations, with aloricate ciliates and tintinnids dominating inshore and large heterotrophic dinoflagellates being most abundant offshore. The inclusion of putative mixotrophs in this analysis made no significant difference to the partition of biomass, and so was ignored.

PCA produced a plausible ordination of the samples which resolved both interstation differences and depth variation. The first 3 components each accounted for similar amounts of sample variability, and together explained $43 \%$ of the total variation (Table 6). A comprehensive picture of the ordination is only obtained when all 3 axes are considered, as each is dominated to a great extent by depth variation at 1 of the 3 stations (Fig. 6). Key taxa determining the variability include bacteria, ciliates, several diatom taxa, dinoflagellates and cryptomonads.

\section{DISCUSSION}

The data presented here provide a 'snapshot' view of microbial processes in the upper water column around South Georgia. Here we consider how representative these data are in the context of other studies in the region, and assess the implications for nutrient cycling and the possible spatial and temporal correlations between the microbial community and nutrient distributions.

\section{Status of the microbial population and the nutrient pool}

The phytoplankton around the island of South Georgia has been studied relatively thoroughly, beginning with the 'Discovery' Investigations (Hart 1934, 1942, Hardy \& Gunther 1935, Hendey 1937). Diatoms appear to be important elements of the phytoplankton throughout the year, including winter (Heywood et al. 1985, Morris \& Priddle 1985). Although some detailed taxonomic investigation of the phytoplankton has been carried out, this is largely restricted to diatoms from net samples (e.g. Theriot \& Fryxell 1985), although Dodge \& Priddle (1986) present data on the spatial variability of photoautotrophic and heterotrophic dinoflagellates around the island. In contrast to the information for larger-celled phytoplankton, the relative contribution of smaller, non-diatom taxa to phytoplankton biomass is only poorly understood for this region.

A few studies of size-fractionated phytoplankton composition in the Southern Ocean, usually based on chlorophyll biomass, suggest that the relatively large contribution of net phytoplankton to total phytoplankton biomass found for South Georgia may be atypical of Antarctic waters as a whole. Bröckel (1981) found that 77 to $87 \%$ of phytoplankton carbon was in the microplankton size fraction $(\geq 20 \mu \mathrm{m})$ for 3 stations near South 
Table 6. Taxa determining the character of the first 3 axes in Principal Component Analysis (PCA) of microbial proportionate biomass for samples from 6 depths at each of 3 stations near South Georgia. Significant loadings have been determined subjectively, and are not consistent between axes. Very rare taxa which nonetheless had significant loadings have been excluded. An ordination of the samples on these principal components is shown in Fig. 6

\section{Principal component 1 (18\% of total variability) \\ Depth gradient for Stn 6, with the $160 \mathrm{~m}$ sample as an outlier (high positive score) from all other samples \\ Positive loadings Proboscia, Gymnodinium spp. \\ Negative loadings Bacteria, Strombidium, Eucampia, Pleurosigma, Protoperidinium, autotrophic nanoflagellates}

\section{Principal component 2 (14\% of total variability)}

Segregates Stn 4 samples (high positive scores) from the remainder, but with very little depth resolution (except negative score for $80 \mathrm{~m}$ sample)

Positive loadings

Negative loadings

Unidentified aloricate ciliate, Cymatocylis, Odontella, Thalassionema

Chaetoceros spp., Protoperidinium, cryptomonads

\section{Principal component 3 (12\% of total variability)}

Provides clear depth profile for Stn 2; positive scores for shallow samples, negative scores for deep

Positive loadings

Negative loadings
Bacteria, unidentified aloricate ciliate, Salpingella, Mesodinium 4 unidentified aloricate species whilst abundances of heterotrophic flagellates are typically higher $\left(10^{8}\right.$ to $\left.10^{9} \mathrm{~m}^{-3}\right)$ but account for similar biomass (2 to $60 \mathrm{mg} \mathrm{C} \mathrm{m}^{-3}$ ) (Garrison 1991). Thus the values obtained in this study accord with the few published data for Antarctic waters.

The role and importance of bacterioplankton in the Antarctic marine euphotic zone have been the subject of speculation. Karl et al. (1991) note that published data for bacterial abundance in the Southern Ocean resemble values for other parts of the world's oceans, with numbers of $10^{7}$ to $10^{9} 1^{-1}$. Bacterial activity in Antarctic waters may also be high (e.g. Hanson et al. 1983, Karl \& Winn 1986). The picture is complicated, however, by apparent uncoupling between bacterial biomass and activity, and primary production (Mullins \& Priddle 1986, Karl et al. 1991). In the present study, bacterial biomass contributed approximately $10 \%$ of total microbial biomass and 15 to $60 \%$ of heterotrophic

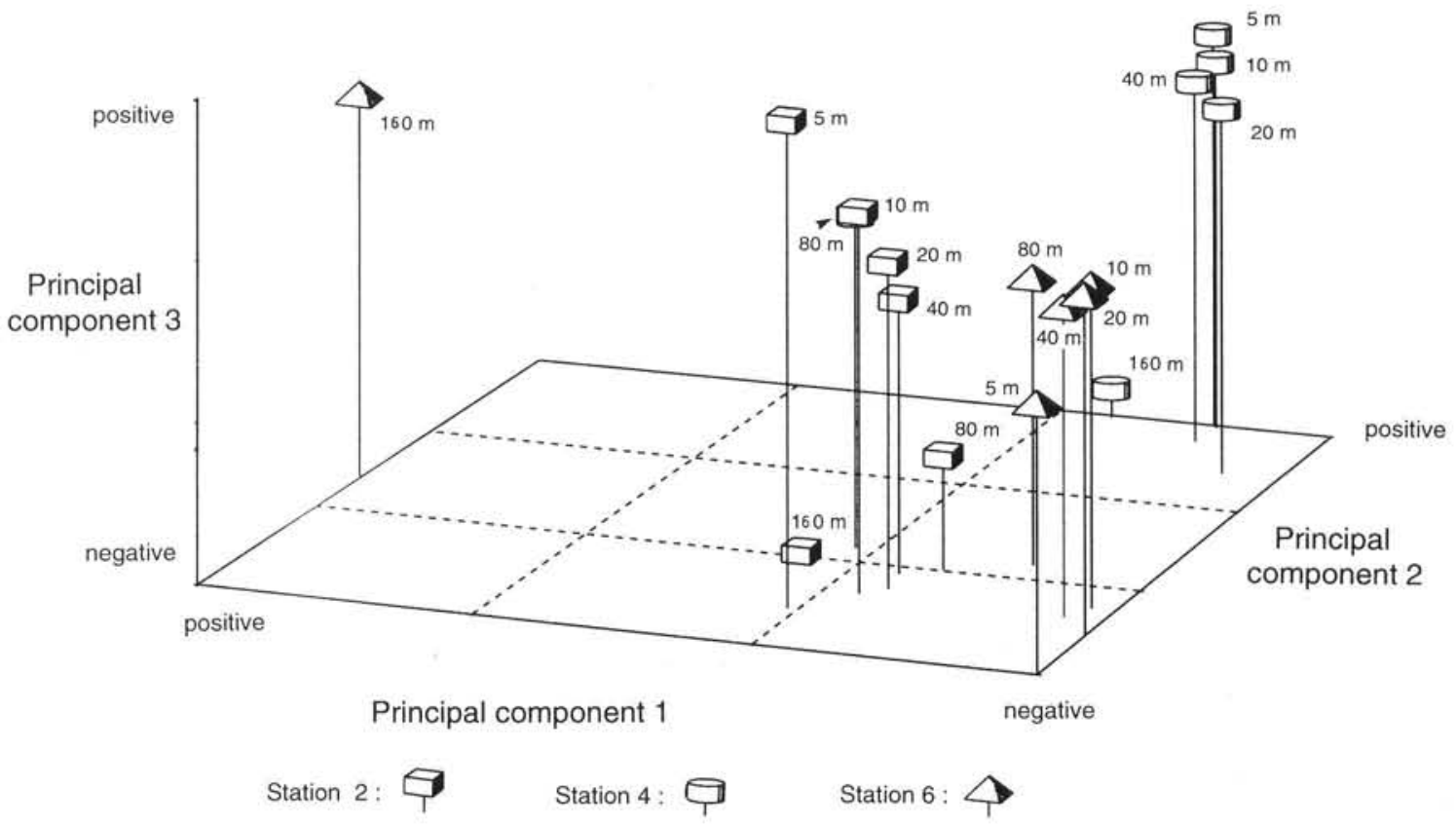

Fig. 6. Three-dimensional plot of the ordination of samples on principal components generated from microbial community composition data. Station symbols are keyed on the figure, and individual samples identified by depth. Composition of the axes is presented in Table 6 
biomass. These values agree with data from 2 studies in Antarctic waters, which found a range of 0.4 to $10 \%$ of total microbial carbon for bacterial biomass from sites in Drake Passage (Hanson et al. 1983) and McMurdo Sound (Hodson et al. 1981).

Inorganic nutrient concentrations in surface water resembled those found in earlier studies around the island. Whitehouse et al. (1993) present data for summer and winter nutrient concentrations in a series of surveys in South Georgia waters. The concentrations of nitrate and phosphate reported here fall within the ranges reported for summer values. Median concentrations of nitrate for 0 to $30 \mathrm{~m}$ depth for 2 summer cruises were 20.3 and $21.7 \mathrm{mmol} \mathrm{m}^{-3}$, and 1.61 and $1.78 \mathrm{mmol} \mathrm{m}^{-3}$ for phosphate, comparing well with median concentrations in the mixed layer at the 3 stations studied here of 17 to $24 \mathrm{mmol} \mathrm{m}^{-3}$ nitrate and 1.6 to $1.7 \mathrm{mmol} \mathrm{m}^{-3}$ phosphate. The values also agree with data of Chlapowski \& Grelowski (1978), whose measurements were concentrated on the northern shelf area of South Georgia in February-March. Their nitrate and phosphate concentrations in surface waters ranged from 15 to 20 and 1.2 to $1.65 \mathrm{mmol} \mathrm{m}^{-3}$ respectively. Silicate concentrations encountered in this study were lower than those measured by Whitehouse and co-workers during 3 summer cruises in the area. Their lowest value was $8.8 \mathrm{mmol} \mathrm{m}^{-3}$, whilst the present study found median concentrations at the 2 offshore sites lower than $1.5 \mathrm{mmol} \mathrm{m}^{-3}$. Chlapowski \& Grelowski (1978) also failed to encounter such low silicate concentrations, recording 4 to $21 \mathrm{mmol} \mathrm{m}^{-3}$ in the surface waters. Although the relative distributions of ASW and Weddell Sea Water (WSW) play an important part in determining the spatial variation in silicate, we have already noted that the very low concentrations at Stn 6 did not correspond to low values in the T-min layer,

Considering the time of year, the biomass and species composition of phytoplankton, we have suggested that the community had already passed through its period of maximum growth, although we would not exclude further population maxima (cf. Owens et al. 1991). This supposition is borne out by the reduction in nutrients in the mixed layer, indicative of primary production in the growing season prior to our visit (see Whitehouse et al. 1993).

\section{Calculation of a nutrient budget for the study region, and its implications for 'new' and 'regenerated' production}

The utilisation and cycling of inorganic nutrients remains a central paradox in the study of microbial ecology in the Southern Ocean pelagic ecosystem, in view of the surplus nutrients generally present in the system (Priddle et al. 1992). Here we use biological, chemical and physical data to compare the use of nutrients, especially inorganic nitrogen, over a range of timescales from diurnal to seasonal. Clearly, with the exception of direct rate measurements, this is dependent on a budget approach. This in turn relies strongly on the selection of baseline levels against which ambient concentrations are compared. We have used the resemblance between the vertical gradients in salinity and nutrients below the mixed layer (Fig. 7) to predict an average nutrient concentration within the mixed layer, on the basis of observed mixed layer salinities. It is apparent that submixed layer nutrient levels exhibit a consistent relationship with salinity, increasing as salinity increases towards the core of the CDW. The mixed layer nutrient concentrations are reasonably similar within each profile and deviate strongly from the regression line relating submixed layer concentrations to salinity. This difference is assumed to be due to biological uptake, although physical processes of concentration or dilution within the mixed layer will alter the apparent relationship between nutrients and salinity (K. Banse pers. comm.). In the present study, dilution appears to be the dominant mechanism and this will result in slight underestimate of nutrient uptake in the mixed layer. Le Jehan \& Tréguer (1983) used a similar technique which related salinity and nutrient concentrations, but with regional rather than singlestation relationships, to estimate nutrient deficits in a study in the Indian Ocean sector of the Southern Ocean. The results of our calculations are presented in Table 7 . We have assumed that all nitrate and silicate in the ASW is derived from the underlying CDW (we have discounted phosphate since we cannot estimate recycling, and ammonium is assumed to arise solely from recycling). This is probably a reasonable assumption for nitrate, but ignores the contribution of silicate from WSW. However, for the purposes of calculating carbon budgets by extrapolation from these nutrient deficits, the likely underestimation arising from this source is not critical.

\section{Daily carbon production rates estimated from measurements of nitrogen uptake}

Owens et al. (1991) measured nitrogen utilisation by microplankton using tracer techniques $\left({ }^{15} \mathrm{~N}\right)$ at Stns 4 and 6 , but did not obtain nitrogen uptake rates for Stn 2. Their rates for Stns 4 and 6, for nitrate-plusammonium uptake integrated over the mixed layer, were equivalent to 0.5 and $0.45 \mathrm{~g} \mathrm{C} \mathrm{m}^{-2} \mathrm{~d}^{-1}$ respectively (assuming Redfield ratio of 106:16 $=6.625$ for $\mathrm{C}: \mathrm{N}$, which is consistent with measured values in this 

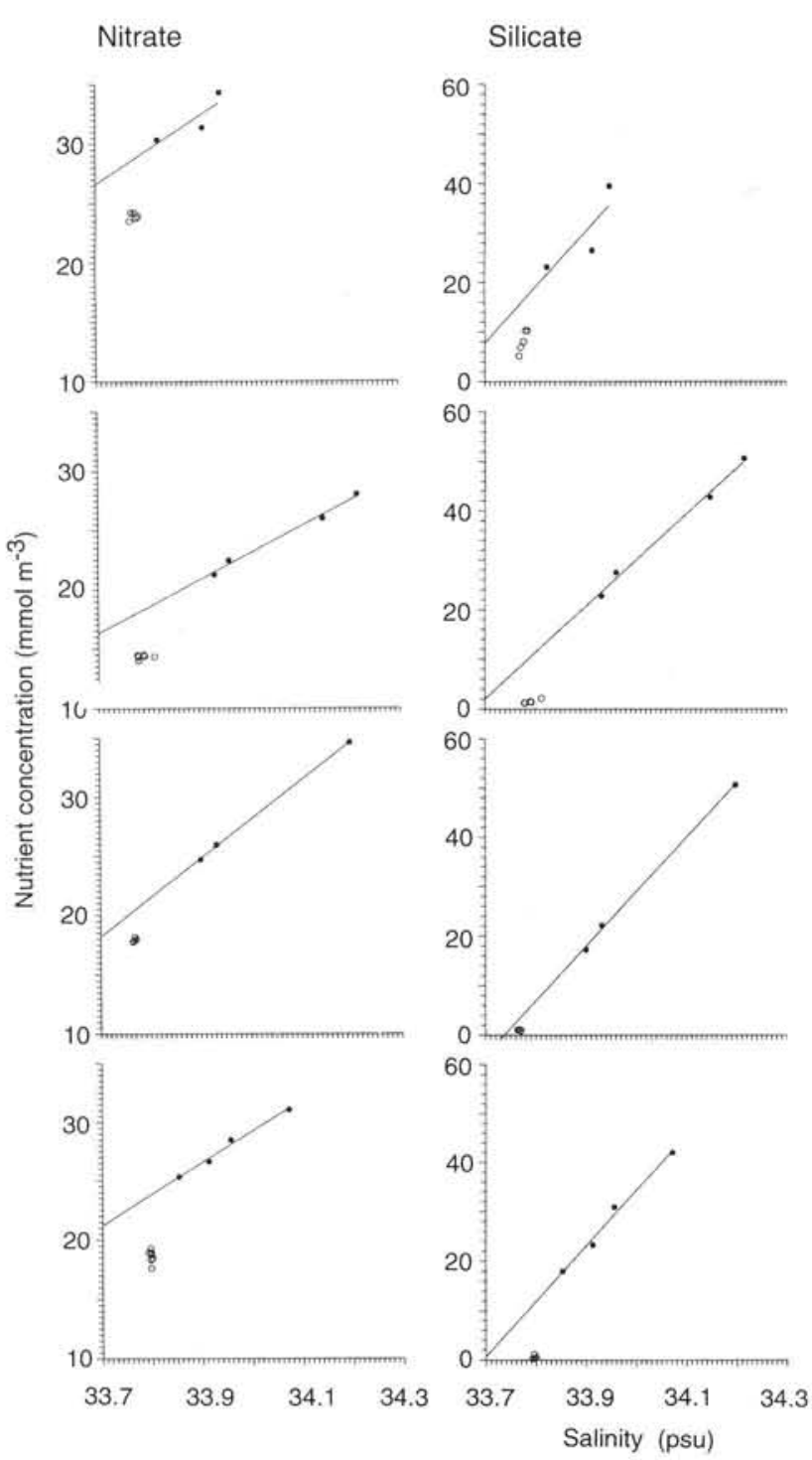

study; Table 3). Corresponding uptake $f$-ratios (proportion of total nitrogen uptake accounted for by nitrate) were 0.8 and 0.62 .

As noted previously, the phytoplankton biomass encountered during this study was lower than the maxima found during other investigations at the same sites, especially slightly earlier in the year. Data from a series of cruises around South Georgia indicate that there is marked spatial and temporal variability during the spring and summer (Priddle et al. 1986, Whitehouse et al. 1993), but that dense diatom blooms with biomass up to $20 \mathrm{mg} \mathrm{chl} \mathrm{m}^{-3}$ may occur locally during the period November-February, perhaps occurring even earlier nearshore. Thus, we would expect that the short-term rates estimated here would not represent the highest nitrogen, and thus carbon, flux rates for the growth season.

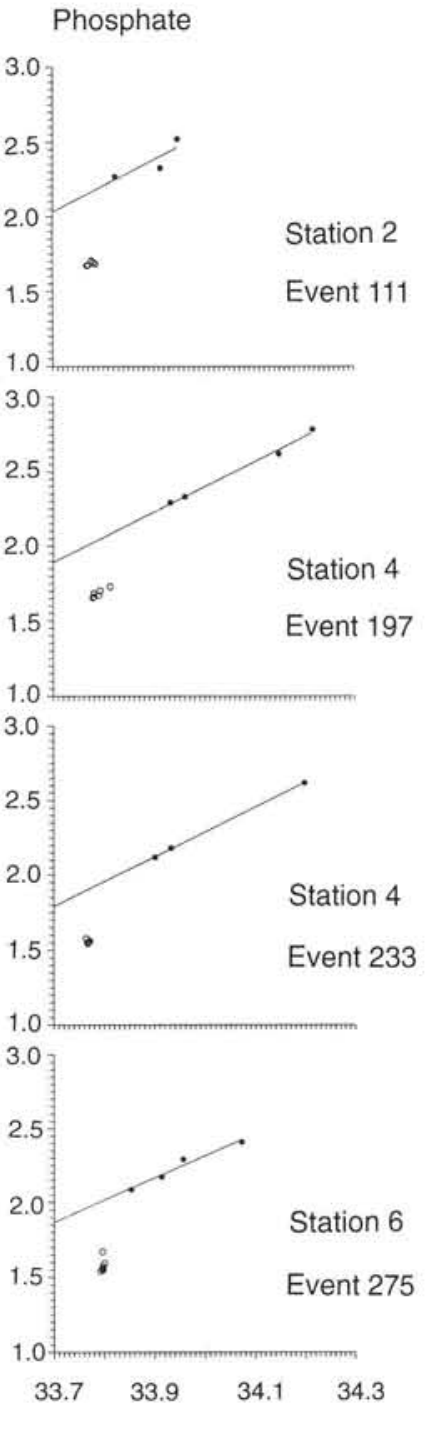

Fig. 7. Relationships between nitrate, phosphate and silicate concentrations and salinity for 3 stations near South Georgia. Data are for single profiles, with 2 separate sampling events from Stn 4. The fitted lines describe the relationship between nutrients and salinity for samples below the mixed layer $(\bullet)$ whilst mixed layer values (o) have uniform salinity and fall below the fitted line

\section{Carbon production estimated from the nitrate deficit}

For this study, it is not possible to calculate absolute nutrient budgets, since the effects of periodic mixing events, shelf break processes, and horizontal advection cannot be quantified (cf. Sambrotto et al, 1993). Here were calculate the apparent biological nitrogen deficit over the mixed layer, scale this to carbon using both Redfield ratio and the observed particulate $\mathrm{C}: \mathrm{N}$ in this study, and then compare this with the carbon production estimates based on the instantaneous N-production values cited above. In the following calculations, carbon is simply used as the 'common currency' to compare rates derived from different measurements $\left({ }^{15} \mathrm{~N}\right.$ instantaneous rates, growing season $\mathrm{NO}_{3}$ and silicate deficits). In all cases, we assume that the ratio between carbon, nitrogen and silicon in both phyto- 
Table 7. Derivation of nutrient deficits for mixed layers at 3 stations near South Georgia. Observed: mean concentrations in the mixed layer (ML); Expected: values predicted by the intersection of the nutrient-salinity regression with ML salinity (see Fig. 7). Concentrations are in $\mathrm{mmol} \mathrm{m}^{-3}$. Difference: expected ML concentration minus observed mean value; Deficit: the difference multiplied by ML depth, in $\mathrm{mmol} \mathrm{m}^{-2}$; Ratio: silicate deficit divided by nitrate deficit

\begin{tabular}{|c|c|c|c|c|}
\hline & $\begin{array}{c}\text { Stn } 2 \\
\text { Event } 111\end{array}$ & $\begin{array}{r}\text { St } \\
\text { Event } 197\end{array}$ & $\begin{array}{l}\text { n } 4 \\
\text { Event } 233\end{array}$ & $\begin{array}{c}\text { Stn } 6 \\
\text { Event } 275\end{array}$ \\
\hline ML depth (m) & 56 & 48 & 50 & 46 \\
\hline \multicolumn{5}{|l|}{ Nitrate } \\
\hline Observed & 24 & 14 & 18 & 19 \\
\hline Expected & 29 & 18 & 20 & 24 \\
\hline Difference & 5 & 4 & 3 & 5 \\
\hline Deficit ( $\mathrm{mmol} \mathrm{m}^{-2}$ & -2) 268 & 188 & 125 & 239 \\
\hline \multicolumn{5}{|l|}{ Silicate } \\
\hline Observed & 8 & 1 & 1 & 0.4 \\
\hline Expected & 16 & 10 & 3 & 11 \\
\hline Difference & 8 & 9 & 2 & 11 \\
\hline Deficit $\left(\mathrm{mmol} \mathrm{m}^{-2}\right.$ & -2) 461 & 421 & 117 & 506 \\
\hline Ratio & 1.72 & 2.22 & 0.93 & 2.12 \\
\hline
\end{tabular}

plankton uptake and the composition of euphotic zone particulate material is nearly constant over the growing season. In the case of $\mathrm{C}: \mathrm{N}$ where our data indicate broad agreement with the classical Redfield proportion, we have used the latter in calculation. This approach would clearly be compromised if there were progressive changes in the relative uptake of dissolved inorganic carbon (DIC) and the other nutrients, as demonstrated by Banse (1994). Banse's argument is based on the varying properties of both the microplankton community and the nutrient pool over the course of the spring bloom in areas where nitrate is utilised fully. At the start of the growing season, recycling of carbon within a plankton community, where nitrate was the major nitrogen source, gave rise to high uptake of $\mathrm{NO}_{3}$ relative to consumption of DIC, whilst conversely DIC uptake continued after nitrate was exhausted at later in the bloom. Particulate C:N also changed systematically in the studies analyzed by Banse, being as low as 4 in the nitrate-uptake phase.

Although such changes might apply in the South Georgia area, we have no data on the composition of particulate material from early in the season to assess the potential impact. However, we note that nitrate concentrations would not have changed markedly through the growth season because of the high initial levels (Whitehouse et al. 1993). During the growing season, the microplankton probably oscillated through several short episodes of high phytoplankton biomass and production, alternating with the more heterogeneous microbial system found during our study (see
Owens et al. 1991, Sakshaug et al. 1991). Thus we suggest that even if the decoupling of carbon and nitrogen uptake suggested by Banse (1994) applied to this study, it would have been limited in effect and would possibly have been smoothed by relatively rapid transitions between net producers and recycling communities.

For the 3 South Georgia stations, subtraction of the mixed layer nitrate concentrations from the predicted mixed layer mean concentrations indicated nitrate deficits over the growth season of 125 to $270 \mathrm{mmol} \mathrm{m}^{-2}$ (Table 7). These values can be converted to carbon uptake: 21, 13 and $19 \mathrm{~g} \mathrm{C} \mathrm{m}^{-2}$ for Stns 2, 4 and 6 respectively [Redfield ratio has been used in this calculation, but the observed values of particulate $\mathrm{C}: \mathrm{N}$ in this study (see Table 3) provide similar numbers]. Clearly, these nitrate deficits cannot be compared directly with the short-term nitrate and ammonium uptake measurements made by Owens et al. (1991) since there is no precise indication of the timescale for the nutrient uptake, other than a plausible estimate of the length of the growing season. In consequence, and because we have no short-term rate measurement for Stn 2, we have had to assume that the rates and uptake $f$-ratios measured by Owens et al. (1991) applied uniformly to the study area through the growth season. If we make these 2 assumptions, the uptake rates measured by Owens and co-workers would result in nitrogen consumption approximately equal to that predicted by the nitrate deficit if the growing season was 40 to $80 \mathrm{~d}$.

Such a growth season is plausible but appears short on the basis of our previous observations. We have already pointed out that we believe that higher phytoplankton production rates would have preceded our study, based on information from other investigations in the area and supported by the evidence of the nutrient pools and microplankton community composition. Thus the length of the growth season inferred from the amount of nitrate removed from the mixed layer would tend towards the lower values suggested here. This appears to be an underestimate of the likely value and thus implies that nitrate removal underestimated carbon uptake by the phytoplankton over the growth season.

\section{Carbon production estimated from the silicate deficit}

Our suggestion that nitrate is underestimating carbon production can be tested by undertaking a similar calculation using the silicate deficit. Since all primary producers should utilize nitrate, whilst only a proportion of the microplankton (predominantly diatoms) will take up silicate, we would expect that silicate would 
underestimate primary production relative to nitrate. Furthermore, advective and other inputs would be likely to further reduce the carbon production estimate produced by the silicate deficit. However, we would also expect biogenic silica to be wholly exported from the mixed layer without significant remineralisation, which would not necessarily be the case for nitrate (Zentara \& Kamykowski 1981, Le Jehan \& Tréguer 1983, Tréguer \& Jacques 1992).

The calculation of carbon production in the euphotic zone using apparent silicate deficits is slightly more problematic because the stoichiometry of carbon and silicon incorporation is poorly defined. Jordan et al. (1991) used published data, largely non-Antarctic, to arrive at a C:Si ratio of approximately 4 for interpreting sedimentation rates of Antarctic diatom blooms. Copin-Montegut \& Copin-Montegut (1978) calculated a value of 2.7 for Antarctic phytoplankton in the Indian Ocean sector of the Southern Ocean. This might be biased by the predominance of highly silicified pennate diatoms. An even lower value of 1.6 was obtained by Smith \& Nelson (1985), again for phytoplankton dominated by pennate diatoms. Data from a single station undertaken $2 \mathrm{wk}$ after the main study provide the only 'local' information for the calculation of a C:Si ratio for particulate material in the South Georgia area (Table 8). This ratio, 4.05 averaged within the euphotic zone, is higher than some other Antarctic data cited here, but is lower than the value of ca 8 given as the oceanic mean by Jacques (1989). The expected ratio of $\mathrm{Si}: \mathrm{N}$ for particulate material in this study would be ca 1.63 , whilst the mean uptake $\mathrm{Si}: \mathrm{N}$ ratio $(\Delta \mathrm{Si} / \Delta \mathrm{N})$ was 1.56 (Table 7).

Calculated silicate deficits are 115 to $505 \mathrm{mmol} \mathrm{m}^{-2}$, and with 1 exception were approximately twice the nitrate deficit (Table 7). The variability at Stn 4 is consistent with its position at the shelf break. We have calculated carbon fixation from these values using both a C:Si value of 4 (corresponding to our own data and many published values) and of 2.5 (taken as an average of the data for silicon-rich Antarctic diatom blooms, from references given above). Use of the higher value produces a carbon fixation estimate which closely resembles that derived from nitrate deficit $-22,12.5$ and $24 \mathrm{~g} \mathrm{C} \mathrm{m}^{-2}$ for Stns 2, 4 and 6 respectively - whilst the corresponding values for $\mathrm{C}: \mathrm{Si}=2.5$ are 14,8 and $15 \mathrm{~g} \mathrm{C} \mathrm{m}^{-2}$. Acceptance of the lower values would imply that primary production was carried out by heavily silicified diatoms alone; these taxa appear to be less typical for the South Georgia zone (Theriot \& Fryxell 1985) than they are for the Indian Ocean sector where low C:Si ratios are found. Furthermore, such a scenario is at variance with our observations of both community composition and particulate C:Si ratio. Le Jehan \& Tréguer (1983) suggested that $\Delta \mathrm{Si} / \Delta \mathrm{N}$ should be ca 3 for the Indian Ocean sector, approximately double our deficit ratio values.

\section{Production and nutrient relationships}

As already noted, we consider that 'biological' nitrate deficit, whilst certainly a conservative estimate of nitrate removal by phytoplankton, is almost certainly an underestimate of phytoplankton growth over the growing season. Both the short growing season suggested by the nitrate flux estimate in comparison with what were probably low values of instantaneous rates, and the indication from silicate uptake that only a proportion of phytoplankton production was represented by nitrate uptake, show that much carbon fixation in the euphotic zone did not give rise to a corresponding decrease in nitrate. This conclusion was also reached in a more detailed and extensive study by Sambrotto et al. (1993). They suggested that over long timescales, nitrate deficit would underestimate carbon export from the euphotic zone because of the more rapid recycling of the organic nitrogen present in sedimenting particulate material. Their conclusion is borne out, inter alia, by their observation of elevated particulate C:N ratios (8.82 at $100 \mathrm{~m}$ depth) at a site in Bransfield Strait (Antarctic Peninsula). This value is very similar to the results obtained in this study (Table 3).

Table 8. Particulate carbon, nitrogen and silicon, and dissolved silicate and nitrate concentrations (all in $\mathrm{mmol} \mathrm{m}^{-3}$ ), for sampling events 673 and 676 (corresponding to Stn 4, but sampled in a later part of the cruise). Nutrient ratios are molar

\begin{tabular}{|cccccrrr|}
\hline Depth $(\mathrm{m})$ & Part. C & Part. N & Part. Si & C:N & C:Si & Diss. Si & Diss. NO ${ }_{3}$ \\
\hline 10 & 37.1 & 6.5 & 8.9 & 5.7 & 4.2 & 1.2 & 17.8 \\
20 & 29.6 & 4.9 & 9.8 & 6.0 & 3.0 & 1.6 & 18.1 \\
40 & 39.0 & 6.1 & 9.3 & 6.4 & 4.2 & 2.1 & 19.0 \\
60 & 21.2 & 3.3 & 4.4 & 6.4 & 4.8 & 23.9 & 18.5 \\
80 & 12.9 & 2.1 & 0.5 & 6.1 & 3.7 & 56.7 \\
200 & 5.2 & 1.1 & 1.4 & 4.7 & & 34.1 \\
\end{tabular}


Our estimates of phytoplankton carbon fixation also appear low in comparison with the requirements for zooplankton grazing fluxes. The carbon flux to copepods and euphausiids (other than krill) alone are estimated to be 0.35 and $0.23 \mathrm{~g} \mathrm{C} \mathrm{m}^{-2} \mathrm{~d}^{-1}$ at Stns 2 and 6 respectively (Ward et al. in press). Uptake at Stn 2 was dominated by grazing of diatoms, whilst at Stn 6 heterotrophic microplankton accounted for nearly half of the flux to grazers (consistent with their proportion of the biomass). If we add consumption by heterotrophic microplankton and other zooplankton (krill, salps), then clearly carbon fixation by phytoplankton must exceed the estimates based on nitrate deficit.

This in turn implies that reduced nitrogen was a significant source throughout the growth season, despite the high concentrations of nitrate typical of ASW. Owens et al. (1991) obtained uptake $f$-ratios of 0.8 and 0.62 for Stns 4 and 6 respectively, indicating significant use of ammonium at the time of measurement. In a review paper, Tréguer \& Jacques (1992) noted the consistently low uptake $f$-ratios recorded in Antarctic studies, with average summer values from a range of locations varying from 0.65 to 0.22 , indicative of the importance of regenerated nitrogen in phytoplankton production in the Southern Ocean despite high nitrate concentrations. This generalisation is, however, not completely applicable, and ice-edge blooms may be more strongly dominated by nitrate utilization (Smith 1991, Kristiansen et al. 1992) The presence of ammonium peaks at the bottom of the mixed layer in this study and significant demineralisation of particulate material (increase in C:N ratio from near-Redfield proportions in the mixed layer to around 10 at the bottom of the pycnocline) are consistent with recycling of significant quantities of nitrogen over the growing season. This agrees with the observations of Rönner et al. (1983) who demonstrated the relatively rapid recycling of nitrogen in the mixed layer in Antarctic waters. Remineralisation of nitrogen in the mixed layer would allow the loss of particulate carbon and silicon from the mixed layer, especially in periods of blooms of large and colonial diatoms (cf. Tréguer \& Jacques 1992, Sambrotto et al. 1993, Sieracki et al. 1993). We cannot estimate the proportions of carbon and nitrogen exported from the euphotic zone, based simply on the particulate C:N ratio. However, the consistency of C:Si ratios in the upper $200 \mathrm{~m}$ of the water column in one sample from this study (Table 8 ) provides an indication if we accept biogenic silica as a conservative property of particulate matter in the upper water column (Le Jehan \& Tréguer 1983, Tande \& Slagstad 1985). This in turn suggests that approximately $25 \%$ of the particulate nitrogen would be remineralised to provide the observed change from near-Redfield C:N in the euphotic zone to values of 8 to 9 immediately below it.

\section{Vertical and horizontal variability in the microbial community}

The microbial community showed distinct vertical gradients at all 3 stations, as indicated both by gross features of the community and in the multivariate analysis of species composition. In particular, heterotrophic and smaller microbes were more abundant in deeper samples than shallow at all stations. The character of the heterotrophic community also varied from station to station. At Stn 2, there was a marked discontinuity between the autotrophic community, dominated by diatoms, in the mixed layer, and a heterotrophic community below the pycnocline. Species correlates were demonstrated by Principal Component 3 of the community analysis, and a microplankton grazing cohort appeared to be located at the base of the mixed layer (high proportion of large heterotrophs, especially dinoflagellates and aloricate ciliates). At the opposite extreme of the horizontal gradient, Stn 6 had a microbial community dominated by heterotroph biomass, principally dinoflagellates in the mixed layer, and nanoplankton and bacteria beneath the mixed layer. Stn 4 was intermediate in character between the 2 other stations, although ciliates rather than dinoflagellates were the dominant 'large' heterotrophs.

In the context of nitrogen cycling, it would be of particular importance to explain the vertical distribution of ammonium and link this to likely functional groups of microbes. However, no particular community or species can be identified with the location of the ammonium peaks in the profiles. This may indicate that nitrogen remineralisation was taking place over most of the mixed layer depth, but that concentrations were reduced at shallow depths by phytoplankton uptake. This explanation seems unlikely, given the similarity between the ammonium profiles for the 3 stations and the significant difference both in microbial biomass and composition. Thus it seems plausible that the ammonium peaks represented localised sites of nitrogen remineralisation, a supposition strengthened by their coincidence with the values of increasing particulate $C: N$, suggesting loss of nitrogen from particulate organic material. Microorganisms responsible for this remineralisation would most probably have been dominated by groups not well resolved by our counting either through insufficient taxonomic resolution (e.g. bacteria, nanoflagellates) or through their association with particulate material.

\section{Conclusion}

Although nitrate utilisation was clearly important in primary production at these sites both during and be- 
fore the study, a significant part of the nitrogen nutrition of the microplankton appeared to be from reduced sources. Nitrate accounted for $>95 \%$ of the inorganic nitrogen (nitrate plus ammonium) in the mixed layer. This suggests that the nitrogen nutrition of phytoplankton may not be well represented by ambient nitrate concentrations, in turn supporting the suggestion that winter nitrate concentration is not a proxy for export production (Sambrotto et al. 1993, Banse 1994, Sambrotto \& Langdon 1994). The convoluted path of nitrogen to the phytoplankton suggested by the present study of microbial nutrient cycling suggests that a simple succession in which nitrate-fuelled new production is followed by a nitrogen-recycling microbial ecosystem is neither a tenable description of the seasonal cycle nor a realistic approach to estimation of export flux. This still prompts the question of why nitrate utilization by phytoplankton is apparently suboptimal, given the very high ambient concentrations - a topic which has received considerable attention over the last few years (e.g. Chisholm \& Morel 1991, Priddle et al. 1992). Utilization of ammonium is more efficient energetically than nitrate (Williams et al. 1979, McCarthy 1980). The direct inhibition of nitrate uptake by ammonium has also been demonstrated (McCarthy 1981, Syrett 1981) and its importance shown for some HNLC areas such as the north Pacific and the Southern Ocean (Wheeler \& Kokkinakis 1990, Miller et al. 1991, Smith 1991). Such inhibition appears to operate at ammonium concentrations within the range detected in the mixed layer at the 3 stations studied here (Olson 1980, Glibert et al. 1982, Wheeler \& Kokkinakis 1990, Smith 1991). Whatever mechanism was acting in the nitrogen cycling at these stations, ammonium concentration and/or availability was clearly a major determinant of primary productivity. Thus microbial nitrogen recycling is likely to be a rate-limiting process for carbon fixation in surface waters, despite high overall dissolved inorganic nitrogen levels. The rapid change in particulate $\mathrm{C}: \mathrm{N}$, accompanied by negligible change in $\mathrm{C}: \mathrm{Si}$, demonstrated in this study indicates that carbon export through the pycnocline can take place in a system which is dominated by regenerated nitrogen.

Acknowledgements. We thank Angus Atkinson and Peter Ward for discussion on zooplankton grazing. A number of useful points were raised the reviewers of this paper, especially by Karl Banse who pointed out the limitations implicit in our nutrient budget calculations. Roger Missing assisted with the preparation of the figures. The work was carried out during a cruise of the RRS 'John Biscoe', and we thank the officers and crew for their help.

\section{LITERATURE CITED}

Atkinson, A., Ward, P., Williams, R., Poulet, S. A. (1992a). Diel vertical migration and feeding of copepods at an oceanic site near South Georgia. Mar. Biol. 113: 583-593

Atkinson, A., Ward, P., Williams, R., Poulet, S. A. (1992b). Feeding rates and diel vertical migration of copepods near South Georgia: comparison of shelf and oceanic sites. Mar. Biol. 114: 49-56

Banse, K. (1994). Uptake of inorganic carbon and nitrate by marine plankton and the Redfield ratio. Global biogeochem. Cycles 8: 81-84

Bratbak, G., Dundas, I. (1984). Bacterial dry matter content and biomass estimations. Appl. environ. Microbiol. 48: 755-757

Bröckel, K. von (1981). The importance of nanoplankton within the pelagic Antarctic ecosystem. Kieler Meeresforsch., Sonderh. 5: 61-67

Chisholm, S. W., Morel, F. M. M. (eds.) (1991). What controls phytoplankton production in nutrient-rich areas of the open sea? (papers from the symposium of the American Society of Limnology and Oceanography). Limnol. Oceanogr. 36: 1507-1965

Chlapowski, K., Grelowski, A. (1978). Hydrographic characteristic of krill fishing grounds explored during the first Polish Antarctic marine research expedition on R/V Professor Siedlecki. Polsk. Arch. Hydrobiol. 25: 535-559

Copin-Montegut, C., Copin-Montegut, G. (1978). The chemistry of particulate matter from the south Indian and Antarctic Oceans. Deep Sea Res. 25: 911-931

Cullen, J. J. (1991). Hypotheses to explain high-nutrient conditions in the open sea. Limnol. Oceanogr. 36: 1578-1599

Dodge, J. D., Priddle, J. (1986). Species composition and ecology of dinoflagellates from the Southern Ocean near South Georgia. J. Plankton Res. 9: 685-697

Dugdale, R. C., Goering, J. J. (1967). Uptake of new and regenerated forms of nitrogen in primary productivity. Limnol. Oceanogr. 12: 196-206

Eppley, R. W., Reid, F. M. H., Strickland, J. D. H. (1970). Estimates of phytoplankton crop size, growth rate and primary production. Bull. Scripps Inst. Oceanogr. 17: 33-42

Garrison, D. L. (1991). An overview of the abundance and role of protozooplankton in Antarctic waters. J. mar. Syst. 2: 317-331

Garrison, D. L., Buck, K. R. (1989). Protozooplankton in the Weddell Sea, Antarctica: abundance and distributions in the ice-edge zone. Polar Biol. 9: 341-351

Garside, C., Garside, J. C. (1993). The 'f-ratio' on $20^{\circ} \mathrm{W}$ during the North Atlantic Bloom Experiment. Deep Sea Res. 40: 75-90

Glibert, P. M., Biggs, D. G., McCarthy, J. J. (1982). Utilization of ammonium and nitrate during the austral summer in the Scotia Sea. Deep Sea Res. 29: 837-850

Hanson, R. B., Lowery, H. K., Shafer, D., Sorocco, R., Pope, D. H. (1983). Microbes in Antarctic waters of the Drake Passage: vertical patterns of substrate uptake, productivity and biomass in January 1980. Polar Biol. 2: 179-188

Hardy, A. C., Gunther, E. R. (1935). The plankton of the South Georgia whaling grounds and adjacent waters, 1926-1927. Discovery Rep. 11: 1-456

Hart, T. J. (1934). On the phytoplankton of the south-west Atlantic and the Bellingshausen Sea. Discovery Rep. 8: 1-268

Hart, T. J. (1942). Phytoplankton periodicity in Antarctic surface waters. Discovery Rep. 21: 261-356

Hendey, N. I. (1937). The plankton diatoms of the Southern Seas. Discovery Rep. 16: 151-364 
Heywood, R. B., Everson, I., Priddle, J. (1985). The absence of krill from the South Georgia zone, winter 1983. Deep Sea Res. 32: 369-378

Hobbie, J. E., Daley, R. J., Jasper, S. (1977). Use of Nuclepore filters for counting bacteria by fluorescence microscopy. Appl. environ. Microbiol. 33: 1225-1228

Hodson, R. E., Azam, F., Carlucci, A. F., Fuhrman, A., Karl, D. M., Holm-Hansen, O. (1981). Microbial uptake of dissolved organic matter in McMurdo Sound, Antarctica. Mar. Biol. 61: 89-94

Jacques, G. (1989). Primary production in the open Antarctic Ocean during the austral summer: a review. Vie Milieu 39: 1-17

Jacques, G. (1991). Is the concept of new production-regenerated production valid for the Southern Ocean? Mar. Chem. 35: 273-286

Jacques, G., Fukuchi, M. (1994). Phytoplankton of the Indian Antarctic Ocean. In: El-Sayed, S. Z. (ed.) Southern Ocean ecology: the BIOMASS perspective. Cambridge University Press, Cambridge, p. 63-78

Jordan, R. W., Priddle, J., Pudsey, C. J., Barker, P. F., Whitehouse, M. J. (1991). Unusual diatom layers in Upper Pleistocene sediments from the northern Weddell Sea. Deep Sea Res. 38: 829-843

Karl, D. M., Holm-Hansen, O., Taylor, G. T., Tien, G., Bird, D. F. (1991). Microbial biomass and productivity in the western Bransfield Strait, Antarctica, during the 1986-87 austral summer. Deep Sea Res. 38: 1029-1055

Karl, D. M., Winn, C. D. (1986). Does adenine incorporation into nucleic acids measure total microbial production? A response to comments by Furhman et al. Limnol. Oceanogr. 31: 1384-1394

Kristiansen, S., Syvertsen, E. E., Farbrot, T. (1992). Nitrogen uptake in the Weddell Sea during late winter and spring. Polar Biol. 12: 245-251

Le Jehan, S., Tréguer, P. (1983). Uptake and regeneration $\Delta \mathrm{Si} / \Delta \mathrm{N} / \Delta \mathrm{P}$ ratios in the Indian Sector of the Southern Ocean. Polar Biol. 2: 127-136

Mantoura, R. F. C., Llewellyn, C. A. (1983). The rapid determination of algal chlorophyll and carotenoid pigments and their breakdown products in natural waters by reversephase high performance liquid chromatography. Analyt. Chim. Acta 151: 297-314

Marchant, H. J., Davidson, A. T., Wright, S. W. (1987). The distribution and abundance of chroococcoid cyanobacteria in the Southern Ocean. Proc. NIPR Symp. Polar Biol. 1: $1-9$

McCarthy, J, J. (1980). Nitrogen. In: Morris, I. (ed.) The physiological ecology of phytoplankton. Blackwell Scientific Publications, Oxford, p. 191-233

McCarthy, J. J. (1981). The kinetics of nutrient utilization. In: Physiological bases of phytoplankton ecology. Can. Bull Fish. Aquat. Sci. 210: 211-233

Miller, C. R., Frost, B. W., Wheeler, P. A., Landry, M. R. Welschmeyer, N., Powell, T. M. (1991). Ecological dynamics in the subarctic Pacific, a possibly iron-limited ecosystem. Limnol. Oceanogr. 36: 1600-1615

Morris, D. J., Priddle, J. (1985). Observations on the feeding and moulting of the Antarctic krill, Euphausia superba Dana, in winter. Bull. Br. Antarct. Surv. 65: 57-63

Mullins, B. W., Priddle, J. (1986). Relationships between bacteria and phytoplankton in the Bransfield Strait and southern Drake Passage. Bull. Br. Antarct. Surv. 76: 51-64

Olson, R. J. (1980). Nitrate and ammonium uptake in Antarctic waters. Limnol. Oceanogr. 25: 1064-1074

Owens, N. J. P., Priddle, J., Whitehouse, M. J. (1991). Variations in phytoplanktonic nitrogen assimilation around
South Georgia and in Bransfield Strait (Southern Ocean). Mar. Chem. 35: 287-304

Paasche, E. (1980). Silicon content of five marine plankton diatom species measured with a rapid filter method. Limnol. Oceanogr. 25: 474-480

Porter, K. G., Feig, Y. S. (1980). The use of DAPI for identifying and counting aquatic microflora. Limnol. Oceanogr. 25: $943-948$

Priddle, J., Heywood, R. B., Theriot, E. (1986). Some environmental factors influencing phytoplankton in the Southern Ocean around South Georgia. Polar Biol. 5: 65-79

Priddle, J., Smetacek, V., Bathmann, U. (1992). Antarctic marine primary production, biogeochemical cycles and climatic change. Phil. Trans. R. Soc. Lond. 338: 289-297

Putt, M., Stoecker, D. K. (1989). An experimentally determined carbon:volume ratio for marine 'oligotrichous' ciliates from estuarine and coastal waters. Limnol. Oceanogr. 34: $1097-1103$

Rönner, U., Sorensson, F., Holm-Hansen, O. (1983). Nitrogen assimilation by phytoplankton in the Scotia Sea. Polar Biol. 2: 137-147

Ryan, B. F., Joiner, B. L., Ryan, T. A. (1988). MINITAB statistical package software, Reference manual release 8. 1. PWS Publishers, Boston

Sakshaug, E., Slagstad, D., Holm-Hansen, O. (1991). Factors controlling the development of phytoplankton blooms in the Antarctic Ocean - a mathematical model. Mar. Chem. 35: 259-271

Sambrotto, R. N., Langdon, C. (1994). Water column dynamics of dissolved inorganic carbon (DIC), nitrogen and $\mathrm{O}_{2}$ on Georges Bank during April, 1990. Cont. Shelf Res. 14: $765-789$

Sambrotto, R. N., Savidge, G., Robinson, C., Boyd, P., Takahashi, T., Karl, D. M., Langdon, C., Chipman, D., Marra, J., Codispoti, L. (1993). Elevated consumption of carbon relative to nitrogen in the surface ocean. Nature 363: 248-250

SAS (1985). SAS user's guide: statistics (version 5). SAS Institute, Inc., Cary, NC

Sieracki, M. E., Verity, P. G., Stoecker, D. K. (1993). Plankton community response to sequential silicate and nitrate depletion during the 1989 North Atlantic spring bloom. Deep Sea Res. 40: 213-225

Smith, W. O. (1991). Nutrient distributions and new production in polar regions, and contrast between the Arctic and the Antarctic. Mar. Chem. 35: 245-258

Smith, W. O., Nelson, D. M. (1985). Phytoplankton bloom produced by a receding ice edge in the Ross Sea: spatial coherence with the density field. Science 227: 163-167

Strickland, J. D. H., Parsons, T. R. (1972). A practical handbook of seawater analysis, 2nd edn. Fisheries Research Board of Canada, Ottawa

Syrett, P. J. (1981). Nitrogen metabolism of microalgae. In: Physiological bases of phytoplankton ecology. Can. Bull. Fish. Aquat. Sci. 210: 182-210

Tande, K. S., Slagstad, D. (1985). Assimilation efficiency in herbivorous aquatic organisms - the potential of the ratio method using ${ }^{14} \mathrm{C}$ and biogenic silica as markers. Limnol. Oceanogr. 30: 1093-1099

Theriot, E., Fryxell, G. A. (1985). Multivariate statistical analysis of net diatom species distributions in the southwestern Atlantic and Indian Ocean. Polar Biol. 5: 23-30

Tien, G., Jones, D., Bailiff, M. D., Nawrocki, M., Tilbrook, B. Haberstroh, P., Taylor, G. T., Karl, D. M. (1987). RACER: spatial and temporal variations in microbial biomass. Antarct. J. U.S. 22: 148-149

Tréguer, P., Jacques, G. (1992). Dynamics of nutrients and phytoplankton, and fluxes of carbon, nitrogen and silicon 
in the Antarctic Ocean. Polar Biol. 12: 149-162

Utermöhl, H. (1958). Zur Vervollkommnung der quantitativen Phytoplankton Methodik. Mitt. int. Verein. theor. angew. Limnol. 9: 1-38

Vincent, W. F. (1988). Microbial ecosystems of Antarctica. Cambridge University Press, Cambridge

Ward, P., Atkinson, A., Murray, A. W. A., Wood, A. G., Williams, R., Poulet, S. A. (in press). The summer zooplankton community at South Georgia: biomass, vertical migration and grazing. Polar Biol

Weber, L. H., El-Sayed, S. Z. (1987). Contributions of the net, nano- and picoplankton to the phytoplankton standing crop and primary productivity in the Southern Ocean. J. Plankton Res. 9: 973-994

Wheeler, P. A., Kokkinakis, S. A. (1990). Ammonium recy- cling limits nitrate use in the oceanic subarctic Pacific. Limnol. Oceanogr. 35: 1267-1278

Whitehouse, M. J., Symon, C. J., Priddle, J. (1993). Variations in the distribution of chlorophyll $a$ and inorganic nutrients around South Georgia, South Atlantic. Antarct. Sci. 5: $367-376$

Whitehouse, M. J., Woodley, V. R. (1987). Automated seawater nutrient analysis. British Antarctic Survey, Cambridge

Williams, P. J. LeB., Rainé, R. C. T., Bryan, J. R. (1979). Agreement between the ${ }^{14} \mathrm{C}$ and oxygen methods of measuring phytoplankton production: reassessment of the photosynthetic quotient. Oceanol. Acta 2: 411-416

Zentara, S. J., Kamykowski, D. (1981). Geographic variations in the relationship between silicic acid and nitrate in the South Pacific Ocean. Deep Sea Res. 28: 455-465

Manuscript first received: March 10, 1994

Revised version accepted: September 29, 1994 